\title{
Peningkatan Produksi Telur Ayam Kampung (Gallus gallus domesticus) setelah Diberikan Serbuk Kunyit (Curcuma longa L.) sebelum Masa Pubertas
}

\section{Increased Production of Chicken Eggs (Gallus Gallus domesticus) After Being Given Turmeric Powder (Curcuma longa L.) Before Puberty}

\author{
Sukarman Hadi Jaya Putra ${ }^{1 *}$ dan Sri Sulystyaningsih Natalia Daeng Tiring ${ }^{2}$ \\ ${ }^{1}$ Program Studi Pendidikan Biologi, Fakultas Keguruan dan Ilmu Pendidikan, \\ Universitas Nusa Nipa. \\ ${ }_{2}^{2}$ Program Studi Pendidikan Kimia, Fakultas Keguruan dan Ilmu Pendidikan, \\ Universitas Nusa Nipa. \\ *Corresponding author: sukarmanputra88@gmail.com
}

Sejarah artikel : Menerima : 08 Desember 2019 Revisi : 13 Februari 2020 Diterima : 17 Juni 2020 Online : 24 Juni 2020

\begin{abstract}
ABSTRAK
Penelitian ini memiliki tujuan untuk mengetahui dampak suplemen serbuk kunyit (Curcuma longa L.) yang diberikan sebelum masuk masa pebertas atau masak kelamin terhadap produksi telur ayam kampung (Gallus gallus domesticus). Bentuk rancangan penelitian adalah rancangan acak lengkap (RAL) dengan jumlah perlakuan sebanyak 3 perlakuan. Perlakuan yang pertama adalah ayam kampung yang tidak diberikan suplemen serbuk kunyit (P0). Perlakuan kedua adalah ayam kampung yang diberikan suplemen serbuk kunyit dengan dosis $216 \mathrm{mg} / \mathrm{ekor} / \mathrm{hari}(\mathrm{P} 1)$. Perlakuan ketiga adalah ayam kampung yang diberikan suplemen serbuk kunyit dengan dosis 324 $\mathrm{mg} / \mathrm{ekor} /$ hari. Untuk 1 perlakuan dibuat 5 kali ulangan. oleh karena itu didapatkan 15 kandang ulangan perlakuan. Masing-masing kandang ulangan perlakuan dimasukkan 3 ekor ayam kampung betina. Masa pemberian perlakuan serbuk kunyit adalah 60 hari, dan dimulai dari saat ayam kampung berumur 4 bulan. Data telur diperoleh dari hasil pengukuran yang dilakukan setiap hari ketika semua ayam sudah bertelur semua. Data satu bulan pengukuran diambil dari 28 hari pengukuran. Semua data pengukuran dianalisis dengan analysis of variance (ANOVA). Jika ditemukan berpengaruh, selanjutnya diuji dengan uji Duncan dengan kepercayaan $95 \%$ ( $(\alpha>0.05)$. Data yang telah dianalisis menjelaskan bahwa ayam kampung yang diberikan suplemen serbuk kunyit memiliki tingkat produksi lebih pada setiap bulan pengamatan dibandingkan dengan ayam yang tidak diberikan suplemen serbuk kunyit sebelum masa pubertas. Dosis serbuk kunyit yang paling tinggi tingkat produksi telur ayam kampung yang dihasil pada setiap bulan pengamatan adalah dosis $324 \mathrm{mg} / \mathrm{ekor} / \mathrm{hari}$. Oleh karena itu, serbuk kunyit memiliki dampak positif pada semakin banyaknya jumlah telur ayam kampung yang dihasilkan setiap bulan.
\end{abstract}

Kata kunci : Curcuma longa L., Gallus gallus domesticus, jumlah telur dan sebelum pubertas.

ABSTRACT

The study has a purpose for knowing the effects of turmeric (Curcuma longa L.) powder supplements Given before entering the period of pebertas or genital cooking against the production of chicken (Gallus gallus domesticus) eggs. The form of research draft is complete random draft (RAL) with the amount of treatment as many as 3 treatments. The first treatment is a village chicken that is not given turmeric powder supplements (P0). The second treatment is the village chicken given the turmeric powder supplement at a dose of $216 \mathrm{mg} / \mathrm{tailed} /$ day $(\mathrm{P} 1)$. The third treatment is the village chicken given the turmeric powder supplement at a dose of $324 \mathrm{mg} /$ tailed/day (P2. For 1 treatment made 5 times replay. Therefore acquired 15 retainment cage treatment. Each of the cage treatment is inserted 3 chicken-tailed chickens. The administration of turmeric powder treatment is 60 days, and starts from the time when the chicken is 4 months old. Eggs Data is obtained from the measurement results performed daily when all chickens are laying all eggs. One month of 
measurement Data is taken from 28 days of measurement. All measurement data is analyzed with analysis of variance (ANOVA). If found influential, further tested with Duncan test with 95\% confidence $(\alpha>0.05)$. The Data that has been analyzed explains that the village chickens given turmeric powder supplements have more production rates on each month of observation compared to chickens that are not given turmeric powder supplements before puberty. The most high turmeric powder dose production rate of chicken eggs produced in each month of observation is dose 324 $\mathrm{mg} /$ tailed/day. Therefore, turmeric powder has a positive impact on the growing number of chickens that are produced each month.

Keywords: Curcuma longa, Gallus gallus domesticus, number of eggs and before puberty.

\section{PENDAHULUAN}

Kebutuhan gizi masyarakat Indonesia mengalami peningkatan. Salah satu faktor yang menentukan tingkat kesejahteraan masyarakat adalah terpunuhinya kebutuhan protein hewani. Pola distribusi energi masyarakat Indonesia adalah; energi yang berasal protein sebanyak 9-14 \%, energi yang berasal dari lemak sebanyak 24-36 \% dan energi yang berasal dari karbohidrat sebanyak 54-63 \% (Hardinsyah, 2010). Tetapi, pencapain tersebut tidak cukup seperti yang diinginkan pemerintah dimana energi dari protein seharusnya 5-15 \%, energi dari lemak seharusnya 25-55 \% dan energi dari karbohidrat seharusnya $40-60 \%$. Data tersebut juga bersesuai dengan nilai konsumsi kalori masyakat kita di tahun 2011 mencapai 1.952,01 kkal, dan mengalami pelemahan nilai konsumsi kalori di tahun 2012 sebesar 99.37 kkal. Dimana nilai konsumsi kalori yang didapat hanya mencapai 1.852, 64 kkal (Respati. Dkk., 2013).

Ternak Ayam kampung (Gallus gallus domestica) merupakan contoh hewan ternak yang bisa memenuhi kebutuhan nutisi pokok masyarakat. Dimana produksi dari ayam kampung seperti telur dan daging ayam dapat menyediakan nutrisi seperti protein (Handarini dkk., 2008). Nutrisi yang terkadung dalam telur ayam petelur cukup tinggi yaitu mengandung protein sebanyak $13,1 \%$ dan lemak sebanyak $11,1 \%$ dalam $100 \mathrm{mg}$ sampel telur. Kandungan yang dimilikinya hampir sama pada telur unggas lainnya seperti telur puyuh dan telur ayam kampung. Kadar kolesterol pada ayam kampung adalah $732 \mathrm{mg} / \mathrm{dl}$, sedangkan puyuh dan ayam kampung adalah berturut-turut $700 \mathrm{mg} / \mathrm{dl}$ (Rahmat dan Wiradimadja, 2011) dan 715 $\mathrm{mg} / \mathrm{dl}$ (Saidin, 2000). Hal tersebut menyebabkan timbulnya keraguan masyarakat dalam mengkonsumsi telur atau daging ayam petelur dalam jumlah banyak.
Bahan eksogen dan endogen adalah unsur utama yang terdapat dalam kolesterol. Eskogen adalah kolesterol yang berasal dari luar tubuh. Berbeda dengan endogen, dimana kolesterol jenis berasal dari dalam tubuh. Kolesterol tersebut merupakan hasil sintesis dari beberapa jaringan tubuh seperti hati (Luis et al., 2014).

Oleh karena itu, ketersediaan kolesterol endogen dipengaruhi oleh kemampuan aktivitas sintesis yang dilakukan oleh usus dan hati untuk menghasilkan kolesterol endogen. Tinggi rendahnya produksi endogen dalam tubuh juga dipengaruhi oleh ketersediaan kolesterol eksogen pada pakan. Semakin tinggi kandungan eksogen dalam pakan, semakin rendah tingkat sintesis endogen yang dilakukan oleh hati dan usus, begitu juga sebaliknya (Piliang dan Djojosoebagio, 2006).

Kolesterol merupakan bahan utama yang dibutuhkan dalam mensintesis hormon reproduksi, seperti steroid dan bahan untuk pembentukan vitelogenin (Salvante et al., 2007). Oleh karena itu, kolesterol digunakan tubuh karena merupakan salah satu bahan yang ada di sel dan juga mempengaruhi aktivitas sel. Dimana, telur dan daging ayam memiliki kandungan lipid yang cukup tinggi.

Hasil penelitian yang menguji kemampuan bahan herbal dam meningkatkan produksi telur pada unggas adalah antara lain; tepung jahe merah diberikan pada ayam kampung (Siahaan, dkk., 2013), serbuk kunyit diberikan pada puyuh (Putra, dkk., 2017), temulawak dan temu putih diberikan pada puyuh (Rondonuwu, dkk., 2014). Oleh karena itu, serbuk kunyit adalah bahan yang baik dalam mengontrol jumlah lipid dalam tubuh. Dimana, lipid pada merupakan faktor yang mempengaruhi kondisi fisiologis dalam meningkatkan hasil produksi unggas, seperti peningkatan produksi telur ayam kampung.

Saraswati et al., (2013a) melaporkan bahwa terjadi penurunan kadar kolesterol 
sebanyak $24.94 \%$ dibanding kontrol. Hewan uji yang digunakan adalah puyuh Jepang, dimana hewan uji tersebut diberikan serbuk kunyit pada masa sebelum pubertas. Kondisi tersebut disebabkan karena adanya pengaruh kurkumin dalam mempengaruhi peningkatan kerja lipoprotein lipase, yang dimana bias berdampak pada rendahnya kandungan trigliserida di darah (Chattopadhyay et al., 2004).

Oleh karena itu, serbuk kunyit tidak hanya menurunkan kadar trigliserida saja, tetapi juga mampu menurunkan kadar kolesterol dalam darah. Penurunan ini disebabkan terpacunya aktivitas sintesis reseptor Low Density Lipoprotein LDL (Emadi et al., 2007).

Putra et al., (2015) dan (Putra dkk., (2016) juga melaporkan bahwa rendahnya kandungan trigliserida dan kolesterol yang ada di kuning telur puyuh Jepang disebabkan karena efek pemberian serbuk kunyit yang diberikan yaitu sebanyak $108 \mathrm{mg} / \mathrm{ekor} / \mathrm{hari}$, tetapi jumlah kandungan tersebut masih belum optimal. Peningkatan dosis suplemen serbuk kunyit sebanyak 3 kali lipat menjadi $324 \mathrm{mg} / \mathrm{ekor} / \mathrm{hari}$ diharapkan mampu mempengaruhi aktivitas metabolisme lemak di tubuh ayam kampung sehingga dapat berdampak pada peningkatan kuantitas produksi ayam kampung.

Uraian latar belakang tersebut menjadi alasan peneliti ingin melakukan penelitian dengan pemberian suplemen serbuk kunyit pada pakan ayam kampung sebelum masak kelamin dengan tujuan untuk meningkatkan produksi telur ayam kampung. Pemberian serbuk kunyit sebelum masak kelamin bertujuan untuk menyesuaikan kondisi fisiologis organ reproduksi pada ayam kampung (Putra, 2017).

\section{METODE PENELITIAN}

Penelitian akan dilaksanakan di Kandang Uji dan Laboratorium MIPA FKIP Universitas Nusa Nipa Maumere. Penelitian dilaksanakan selama satu tahun yaitu dari Januari sampai dengan Desember tahun 2019.

Metode dalam penelitian ini menggunakan system RAL atau rancangan acak lengkap. Hewan uji berupa ayam kampung (Gallus gallus domesticus). Jumlah ayam kampung yang digunakan adalah 45 ekor ayam kampung betina. 45 ekor sampel tersebut diambil acak dari 100 ekor ayam kampung betina yang sudah berumur 4 bulan. Seluruh sampel dibagi menjadi 3 kelompok perlakuan. 1 kelompok perlakuan dibagi lagi menjagi 5 kelompok ulang perlakuan. Oleh karena itu, 1 ulangan perlakuan terdiri dari 3 ekor ayam kampung betina. Selanjutnya pada umur enam bulan dilakukan pengukuran jumlah telur. Jumlah telur diukur setiap bulan. Data telur diambil setiap hari dan dilakukan pendataan ketika sudah 28 hari. Variabel yang dianalisis adalah jumlah telur pada setiap bulan pengamatan yaitu pengamata bulan ke-1 dan pengamatan bulan ke-2.

\section{Perlakuan}

Jumlah perlakuan serbuk kunyit terdiri dari 3 perlakuan. Perlakuan pertama adalah 0 $\mathrm{mg} / \mathrm{ek}$ r/hari, perlakuan kedua adalah 216 $\mathrm{mg} / \mathrm{ekor} /$ hari dan perlakuan ketiga adalah 324 mg/ekor/hari (Putra, 2017). Adapun data parameter yang diamati pada penelitian ini adalah produksinya yaitu jumlah telur ayam kampung yang dihasilkan pada setiap bulan pengamatan.

\section{Alat dan Bahan}

Alat-alatnya adalah kandang puyuh, neraca analitik, timbangan, ember, alat tempat air minum, termometer, higrometer dan tempat pakan. Bahan-bahannya adalah ayam kampung berumur 4 bulan yang belum masuk masak kelamin, serbuk kunyit dan telur.

\section{Prosedur Penelitian}

Tahap persiapan

Persiapan Serbuk Kunyit

Pada permulaan, peneliti menyiapkan rimpang kunyit segar sebanyak $16 \mathrm{~kg}$. Rimpang yang diambil adalah rimpang tertua dari kunyit (Curcuma longa L.). Rimpang tersebut kemudian diperlakukan sedemikian hingga supaya bias menghasilak serbuk kunyit dengan kondisi sudah tidak basah/atau mengandung air. Proses yang dilakukan untuk mendapatkan serbuk kunyit, antara lain; kunyit terlebih dahulu dikupas, kemudian dicuci, selanjutnya dikeringkan dibawah naungan yang tidak terkena matahari secara langsung sampai kadar air menjadi $30 \%$, selanjutnya digiling. Pembuatan serbuk kunyit dilakukan di laboratorium MIPA FKIP Universitas Nusa Nipa.

Serbuk kunyit yang sudah diproses tadi selanjutnya ditimbang sesuai perlakuan dosis yang dibutuhkan yaitu yaitu 216 mg/ekor/hari 
dan $324 \mathrm{mg} / \mathrm{ekor} / \mathrm{hari}$. Setiap dosis dicampurkan dengan pakan standar untuk unggas yaitu pakan pellet ayam sebanyak $100 \mathrm{gr} / \mathrm{kandang} / \mathrm{hari}$. Untuk mempermudahkan percampuran pakan standar dengan serbuk kunyit, diberikan semprotan air sebanyak 20 kali semprot (sampai serbuk kunyit bercampur), lalu diaduk hingga tercampur rata. Proses selanjutnya pengeringan pada tempat yang tidak terkena sinar matahari secara langsung.

Tahap pelaksanaan

Campuran pakan standar yang mengandung $100 \mathrm{~g}$ serbuk kunyit diberikan setiap pagi pukul 06.00 WIB pada setiap kandang sesuai dengan perlakuan. Serbuk kunyit diberikan sebelum masak kelamin mulai sejak umur 4 bulan selama 60 hari.

Pengukuran variabel penelitian

Jumlah telur dihitung mulai ketika semua sampel ayam kampung sudah bertelur semua, kemudian didata jumlah telurnya setiap hari dan diakumulasikan saat sudah mencapai 28 hari. Masa 28 hari tersebut dijadikan sebagai data pengamatan jumlah telur perbulan.

\section{Analisis data}

Software analisisnya adalah software SAS, kemudian dilanjutkan dengan uji LSD (Least Significant Difference) dengan kepercayaan $95 \%$ yaitu $(\alpha<0.05)$ (Mattjik, 2006).

\section{HASIL DAN PEMBAHASAN}

Hasil pengamatan bulan ke-1 dan bulan ke-2 dianilisis secara statistic. Hasil analisis pada kedua bulan pengamatan menunjukkan bahwa ayam kampung yang diberikan serbuk kunyit pada pakan standar sebelum masa pubertas memberikan hasil yang signifikan, dimana nilai $P$ kurang dari $0.05 \quad(P<0.05)$. Grafik dan histogram perbandingan data produksi telur pada dua bulan pengamatan tersaji pada Gambar 1.

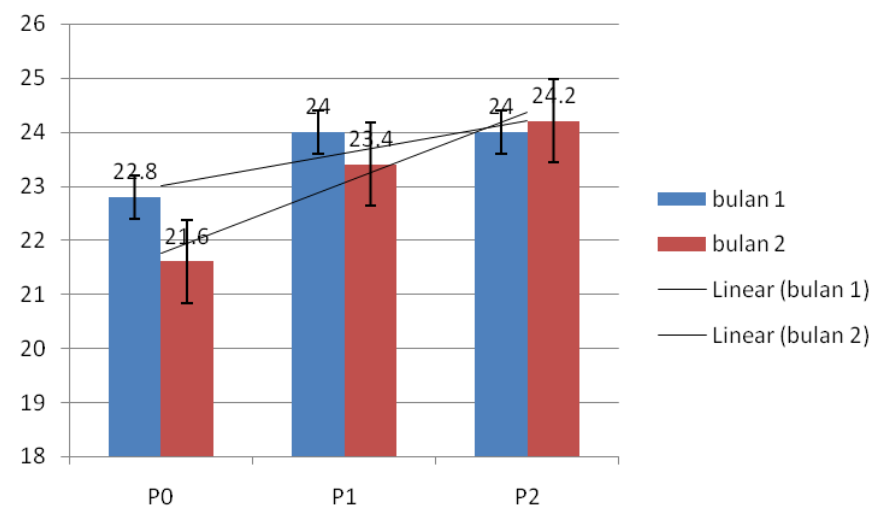

Gambar 1. Jumlah telur ayam kampung setelah diberikan serbuk kunyit sebelum masa pubertas pada setiap bulan pengamatan.

Hasil pengamatan setiap bulan menginformasikan bahwa serbuk kunyit berdampak signifikan $(\mathrm{P}<0.05) \quad$ dalam meningkatkan jumlah produksi telur ayam petelur yang diberikan sebelum masuk masa pubertas atau masak kelamin.

Terjadinya peningkatan jumlah telur ayam kampung pada pengamatan bulan ke-1. Dimana pengamatan pada perlakuan dengan dosis $216 \mathrm{mg} / \mathrm{ekor} / \mathrm{hari}$ dan perlakuan dengan dosis $324 \mathrm{mg} / \mathrm{ekor} / \mathrm{hari}$ sama-sama menghasilkan 24 butir/bulan pengamatan. Sedangkan perakuan kontrol yang tidak diberikan suplemen serbuk kunyit hanya menghasilkan 22,8 butir/bulan pengamatan.
Artinya pada bulan ke-1, ayam petelur yang diberikan perlakuan serbuk kunyit lebih tinggi produksinya dibandingkan kontrol.

Adapun, jumlah telur pada pengamatan bulan ke-2 juga terlihat adanya peningkatan seperti pada pengamatan bulan ke-1. Jumlah telur paling tinggi terdapat pada ayam kampung yang diberikan perlakuan dengan dosis $324 \mathrm{mg} / \mathrm{ekor} /$ hari yaitu 24,2 butir. Sedangkan, pada control hanya mencapai 21, 6 butir dan perlakuan dengan dosis $216 \mathrm{mg} /$ ekor/hari hanya mencapai 23,4 butir.

Ayam kampung yang diberikan serbuk kunyit mengalami peningkatan jumlah 
telur ayam kampung pada setiap bulan pengamatan. Dosis serbuk kunyit sebanyak $324 \mathrm{mg} / \mathrm{ekor} /$ hari lebih berdampak positif dalam meningkatkan produksi telur ayam petelur dibandingkan dengan dosis perlakuan lainnya. Jumlah telur yang dihasilkan ayam kampung pada setiap bulan pengamatan juga semakin meningkat. Perlakuan dengan dosis $324 \mathrm{mg} / \mathrm{ekor} /$ hari pada pengamatan bulan ke1 adalah 24 butir, dan meningkat menjadi 24,2 butir pada pengamatan bulan ke-2. Serbuk kunyit memiliki dampak positif pada peningkatan jumlah telur unggas. Luthfi dkk. (2015) melaporkan bahwa puyuh yang diberikan larutan kunyit dengan dosis paling tinggi memiliki produksi telur paling tinggi yaitu mencapai $70,31 \%$, dibandingkan kontrol yang hanya mencapai $58,03 \%$.

Peningkatan jumlah telur ayam kampung karena pemberian serbuk kunyit sebelum masak kelamin dindikasikan karena pengaruh kurkumin dan fitoestrogen pada kunyit. Kandungan fitoestrogen pada kunyit mencapai 6,73 \% (Saraswati et al. 2013). Sengupta et al. (2011) melaporkan bahwa kurkumin memiliki peran dalam mengoptimalkan fungsi hati ketika melakukan metabolisme lipid. Contohnya adalah terjadi peningkatan aktivitas lipoprotein dalam mengontrol kolesterol dan trigliserida dalam jaringan tubuh (Grahame, 2012). Levi et al. (2009) menjelaskan bahwa fitoestrogen pada kurkumin meberikan efek yang sama seperti hormon estrogen. Fitoestrogen bertugas memacu aktivitas sintesis vitelogenin di hati. Dimana hasil sintesis tersebut dimanfaatkan sebagai sebagai prekursor dalam sintesis vitelogenin.

Salama et al., (2013) menjelaskan bahwa terjadi peningkatan jumlah telur ayam ketika sudah diberikan serbuk kunyit sebelum masuk masa pubertas, karena hal itu adalah bentuk indikasi terjadi aktivitas fitoestrogen dalam meningkatkan sintesis vitolegenin (Salama et al., 2013). Dengan adanya aktivitas fitoestogen dalam meningkatkan sintesis vitoleginin, maka itu berarti kunyit dapat membantu kinerja estrogenik pada unggas (Ravindran et al., 2007). Fitoestrogen dapat terikat pada reseptor estrogen. Potensi estrogenik pernah diteliti pada ikan. Dimana jika ikan diberikan fitoestrogen maka akan terjadi perubahan kandungan vitolegenin dalam darah (Turker and Bocaarmutlu, 2009).
Metabolismen lipid seperti vitelogenin yang dihasilkan oleh hati akan akan terdistribusi ke seluruh jaringan tubuh. Contohnya adalah hierarki folikel di unggas. Produksi telur akan meningkat jika kandungan vitelogenin dalam hierarki folikelnya terkandung dalam jumlah banyak. Oleh karena itu, akan terbentuk jumlah hierarki folikel lebih banyak, sehingga dapat dihasilkan jumlah telur yang banyak juga. Putra, (2017) melaporkan bahwa jumlah hierarki folikel mengalami penambahan yang signifikan pada ovarium puyuh Japang yang diberikan campuran serbuk kunyit pada pakan standarnya.

Peningkatan tersebut disebabkan karena kondisi fisiologis ayam kampung dalam kondisi baik. Hal tersebut sesuai dengan hasil penelitian Putra et al., (2015), bahwa puyuh jepang yang diberikan campuran serbuk kunyit pada pakannya berdampak pada rendahnya kandungan trigliserida di hati, serum dan karkas. Selain itu, kualitas telur juga meningkat pada puyuh yang diberikan perlakuan sama, dimana kandungan kolesterol pada karkas dan telur (Putra dkk, 2016) dan kolesterol hati (Putra dan Mansur, 2017) lebih rendah dibandingkan puyuh yang tidak mendapat perlakuan

Kondisi kadar lipid tersebut mempengaruhi kondsi fisiologis pada unggas. Karena lipid adalah bahan dasar yang digunakan untuk mensintesis vitelogenin. Sintesis tersebut terjadi di dalam jaringan tubuh seperti hati dan usus. Lipid didistribusi dari hati, daging, dan darah. Ini menunjukkan bahwa kurkumin memiliki efek estrogenik dalam meningkatkan jumlah telur pada unggas. Kondisi fisiologis yang optimal tersebut berdampak baik pada meningkatnya jumlah telur ayam kampung setelah diberikan serbuk kunyit sebelum masa pubertas.

\section{KESIMPULAN}

Serbuk kunyit dengan dosis 324 mg/ekor/hari mampu meningkatkan jumlah telur ayam kampung sampai 24 butir pada bulan 1 dan 24 butir pada bulan ke-2.

\section{Acknowledgement}

Terimakasih kepada Kementrian Riset dan Teknologi atas terpilihnya penelitian sebagai salah satu pemenang dana hibah Ristek Dikti tahun anggaran 2019. 


\section{DAFTAR PUSTAKA}

Biswas. A., Mohan. J., Venkata. K., and Sastry. H. 2010. Age-Dependent Variation in Hormonal Concentration and Biochemical Constituens in Blood Plasma of Indian Native Fowl. Veterinary Medicine International 737292: 1-5.

Chandrashekar. T. R., Zaczek. D. and Bartke. A. 2004. The Consequences of Altered Somatotropic System on Reproduction. Biology of Reproduction 71: 17-27.

Chattopadhyay. I., Biswa. K., Bandyopadhyay. $U$ and Banerjee. R. K. 2004. Tumeric and Curcumin: Biological Action and Medicinal Applications. Current Science 87(1): 44-53.

Clinical Approach. Williams and Wilkins: Philadelphia. Hal. 478-531.

El-Sayyad. H. I., Abou-El-Naga. A. M., Gadallah. A. A., and Bakr. I. H. 2010. Protective Effects of Allium sativum Against Defects of Hypercholesterolemia on Pregnant Rats and Their Off Spring. International Journal of Clinical Experimental Medicine 3(2):152163.

Emadi. M, Kermanshahi. $\mathrm{H}$ and Maroufyan. E. 2007. Effect of Varying Levels of Tumeric Rhizome Powder on Some Blood Parameters of Broiler Cickens Fed Corn-Soyben Meal Based Diets. International Journal of Poultry Science 6 (5):345-348.

Handarini. R. Saleh. E. dan Togatorop. B., 2008. Produksi Burung Puyuh yang Diberi Ransum Dengan Penambahan Tepung Umbut Sawit Fermentasi. Agribisnis Peternakan, Vol. 4. No. 3. Hal. 107.pi

Hardinsyah, Hadi. R. dan Victor. N. 2010. Kecukupan Energi, Protein, Lemak, dan Karbohidrat. Departemen Gizi Masyarakat. Fakultas Ekologi Manusia. Institut Pertanian Bogor. Bogor.

Hussein. M.A and Farghaly. H.S. 2010. Protective Effect Of Curcumin Against Paracetamol-Induced Liver Damage. Australian Journal of Basic and Applied Sciences 4(9): 4266-4274.

Kohli. K., Ali. J., Antasari. M. J and Rahemen. Z. A. 2005. Natural Antiinflamatory
Agent. Education forum 37(3): 141 147.

Levi. L., Pekarski. I., Gutman. E., Fortina. P., Hyslop. T., Biran. J., Levavi. B and Lubbzens E. 2009. Licensee Biomed Central Ltd.http://www.biomedcentral.com/1 471-2164/10/141

Luís. M, Luís M. B. B. Estronca, Hugo A. L. Filipe, Armindo. S, Maria. J, Moreno and Winchil L. C. 2014. Homeostasis Of Free Cholesterol in The Blood - A Preliminary Evaluation and Modeling Of Its Passive Transport. Journal Of Lipids Reaseacrh. Biological Chemistry Group, Chemistry Department FCTUC, Largo D. Dinis, Rua Larga, 3004-535 Coimbra, Portugal.

Luthfi. M., Nur. H., and Anggraeni. 2015. Effect of the inclusion of turmeric (Curcuma domestica) extract solution in drinking water on the eggs yields of quail. Jurnal Peternakan Nusantara. Vol. 1. No. 2. 2015: 81-88

Marks. A.D., Marks. D.B., and Smith. C.M. 2000. Basic Medical Biochemistry:A

Mattjik. A. A dan Sumertajaya. I. M. 2006. Perancangan Percobaan dengan Aflikasi SAS dan MINITAB. Ed ke3. Bogor:IPB Press

Mouler. M. R., Bar-Yishay. I., Fishman. S., Adamovich. Y., Shaul. Y., Halpern. Z. and Shlomai. A. 2010. Curcumin Inhibits Hepatitis B Virus Via DownRegulation of The Metabolic Coactivator PGC-1a. Federation of European Biochemical Societies Letters 584: 2485-2490.

Murray. R. K., David. A. B., Kathlam. M. B., Peter. J. K., Victor. W. R, and Ambong. P. W. 2009. Lipids of Physiologic Significance; Harper's Illustrated Biochemistry $28^{\text {th }}$ Edition. The McGraw-Hill Companies: United States of America. Hal. 121130

Negi. A.S., Kumar. J.K., Luqman. S., Shanker. K., Gupta. M.M and Khanuja. S. P.S. 2007. Recent Advances in Plant Hepatoprotectives: A Chemical And Biological Profile of Some Important Leads. Medical Research Reviews 28 (5): 746-722. 
Peter. J. K and Kathleen. M. B. 2009. Lipid Transport \& Storage; Cholesterol Synthesis, Transport, \& Excretion; Harper's Illustrated Biochemistry 28 th Edition. The McGraw-Hill Companies: United States of America. Hal. 215-232.

Piliang. W. G dan Djojosoebagio. L. 2006. Fisiologi Nutrisi. Vol. I. Edisi Revisi. IPB press.

Puastuti. W. 2001. Pengaruh Pemberian Temulawak (Curcuma xanthorrhiza Roxb.) dan Minyak Kelapa dalam Ransum Terhadap Kadar Lemak dan Kolesterol Telur. Seminar Nasional Teknologi Peternakan dan Veteriner. 609-615.

Putra, S.H.J. 2018. Profile of High Density Lipoprotein (HDL) and Low Density Lipoprotein (LDL) Japanese Quail Serum (Coturnix-coturnix japonica L.) After Provision of Turmeric Powder Supplement (Curcuma longa L.). Biota. Jurnal Biologi dan Pendidikan Biologi. Vol. 11 No. 1. 2018: 26-39.

Putra, S.H.J. dan Mansur, S. (2017). Pengaruh Pemberian Suplemen Serbuk Kunyit (Curcuma longa L.) terhadap Kadar Kolesterol Hati Puyuh Jepang (Coturnix coturnix japonica L.). Mangifera Edu. Vol. 11(1): 25-31.

Putra, S.H.J., 2017. Efektifitas Pemberian Suplemen Serbuk Kunyit (Curcuma longa L.) terhadap Jumlah Telur dan Bakal Telur (Hierarki folikel) Puyuh Jepang (Coturnix coturnix japonica L.). Biota. Jurnal Biologi dan Pendidikan Biologi. Vol. 10 No. 2. 2017: 114-126.

Putra, S.H.J., Saraswati, T.R., Isdadiyanto, S. (2015). Bobot Lemak Abdomen dan Lemak Subkutan Puyuh Jepang (Coturnix coturnix japonica) setelah pemberian serbuk kunyit (Curcuma longa). Prosiding Seminar Nasional II 2015. Magister Biologi, Fakultas Sains dan Matematika, Universitas Diponegoro. Semarang. No. 10.

Putra, S.H.J., Saraswati, T.R., Isdadiyanto, S. (2015). Profile Triglycerides Japanese Quail (Coturnix coturnix japonica) after Giving Turmeric (Curcuma longa) Powder. International Journal of Science and Engineering Vol. 8 (1): 65-68.
Putra, S.H.J., Saraswati, T.R., Isdadiyanto, S. (2016). Kadar kolesterol kuning telur dan daging puyuh jepang (Coturnix coturnix japonica) setelah pemberian suplemen serbuk kunyit (Curcuma longa). Buletin Anatomi dan Fisiologi, dh Sellula. Vol. 24 (1): 108-114.

Rahmad. D. dan Wiradimadja. R. (2011). Pendugaan Kadar Kolesterol Daging dan Telur Berdasarkan Kadar Kolesterol Darah pada Puyuh Jepang. Jurnal IImu Ternak $11(1): 3538$.

Ravindran. P. N., Babu. K. N and Sivaraman. K. 2007. Tumeric. The Genus Curcuma. CRC Press London: New York. Hal. 375-376.

Respati. E., Hasanah. L., Wahyuningsih. S., Sehusman, Manurung. M., Supriyati. Y dan Rinawati. 2013. Pusat Data dan System Informasi Pertanian. Bulletin Konsumsi Pangan 4 (2): 1-56.

Rondonuwu. C., Saerang. J.L., Nangoy. F.J., dan Laatung. S. 2014. Penambahan Rimpang Kunyit (Curcuma domestica val.), Temulawak (Curcuma xanthorrhiza roxb.), dan Temu Putih (Curcuma zedoaria rosc.) dalam Ransum Komersil Terhadap Kualitas Telur Burung Puyuh (Coturnix-coturnix japonica. Jurnal zootek ("Zootek" Jurnal) Vol 34 No 1. 2014: 106-113

Saidin. M. 2000. Kandungan Kolesterol dalam Berbagai Bahan Makanan Hewani. Buletin Penelitian Kesehatan 27 (2): 224-230.

Salvante. K. G, Li. G, Walzem. R. L and Williams. T. D. 2007. Characterization of Very Low Density Lipoprotein Particle Diameter Dynamics in Relation To Egg Production in a Passerine Bird. The Journal of Experimental Biology 210: 1064-1074

Sandeep. G. K., Amit. L., Vinay. J., Siddartha. G., Jyoti and Anju. K. 2010. Phytochemistry of Curcuma Longa an Overview. Journal of Pharmaceutical and Biomedical Science 4(1):1-8.

Saraswati, T.R., Wasmen. M., Damiana. R. E. and Nastiti. K. 2013. Increased Egg Production of Japanese Quail (Cortunix coturnix japonica L.) by 
Improving Liver Function Through Turmeric Powder Supplementation. International Journal of Poultry Science 12 (10): 601-614.

Saraswati. T.R. 2013 ${ }^{\text {a }}$. The Role Of Turmeric Powder In Lipid Metabolism And Its Effect On Quality Of The First Quail's Egg. Turmeric Effect on Lipid Metabolism and Egg Quality. 38(2)2013p123-130.

Saraswati. T.R. 2013 . Optimization Of Physiological Conditions Japanese Quail (Coturnix Coturnix Japonica) With Turmeric Powder Supplementation (Curcuma Longa). Bogor Agricultural University. DT Veterinary Science [151]

Sengupta. M., Sharma. G.D and Charaborty. B. 2011. Hepatoprotective and Immunomodulatory Properties Of Aqueous Extract of Curcuma Longa in Carbon Tetra Chloride Intoxicated Swiss Albino Mice. Asian Pacific Journal of Tropical Biomedicine 1 (3): 193-199.

Siahaan. N.B., Suprijatna. E., dan Mahfudz. L. D. 2013. Pengaruh penambahan Tepung Jahe Merah (Zingiber officinale

var. Rubrum) Dalam Ransum Terhadap Laju Bobot Badan dan Produksi Telur Ayam Kampung Periode Layer. Animal Agricultural Journal. Vol. 2. No. 1, 2013: 478488

Somchit. M. N., Zuraini. A., Bustamam. A., Sulaiman. M. R and Nuratunlina. R. 2005. Protective Activity of Turmeric (Curcuma Longa) in Paracetamol Induced-Hepatotocity in Rat. International Journal of Pharmacology 1(3): 252-256.

Turker. $\mathrm{H}$ and Bocaarmutlu. 2009. Effect of Total Isoflavones Faound in Soybean On Vitelogenin Production in Commeon Carp. af as niversitesi eteriner a Itesi Dergisi 15(4): 561 568 